\title{
Organizing the Home Front: The American Women's Voluntary Services in New Jersey during World War II
}

\section{By Patricia Chappine}

\section{DOI: https://doi.org/10.14713/njs.v8i1.264}

During World War II (WWII), the American Women's Voluntary Services (AWVS) became the largest service organization in the U.S. At the onset of American entry into WWII, the AWVS already included 18,000 volunteers. Within two years of its creation, the group expanded to 350 chapters nationwide, with the height of its wartime membership reaching roughly 325,000. ${ }^{1}$ Both on a national and local level, the AWVS proved instrumental to the success of home-front mobilization during WWII. With numerous community chapters, significant wartime initiatives, and proximity to the national AWVS in New York City, the New Jersey groups serve as a starting point for a more nuanced reflection on the AWVS during WWII. Along with considerations of gendered citizenship and volunteerism, the narrative of the AWVS presents women who both adhered to accepted forms of volunteerism and pushed social boundaries. ${ }^{2}$ The activities of the AWVS occupied a space somewhere in between nurturing and militaristic, blurring gendered lines of acceptable wartime participation and occupying a unique role not easily categorized. These women reimagined local activism and cooperation as encompassing more than their socially accepted supporting roles and expanded into areas of civilian defense, disaster response, emergency preparedness, and more.

\section{"Of all the volunteer groups, the one that made the most noise was the American Women's Voluntary Services. ...."3}

\footnotetext{
${ }^{1}$ Doris Weatherford, American Women and World War II (Edison, NJ: Castle Books, 1990), 233.

${ }^{2}$ According to Meghan K. Winchell, gendered citizenship was work performed by women that "reinforced their primary peacetime roles as mothers and caregivers" ("To Make the Boys Feel at Home': USO Senior Hostesses and Gendered Citizenship" Frontiers: A Journal of Women's Studies, Vol. 25, No. 1 (2004): 191).

3 “Civilian Defense: The Ladies!” Time, Monday, Jan. 26, 1942.
} 
During World War II (WWII), the American Women's Voluntary Services (AWVS) became the largest service organization in the U.S. At the onset of American entry into WWII, the AWVS already included 18,000 volunteers. Within two years of its creation, the group expanded to 350 chapters nationwide, with the height of its wartime membership reaching roughly $325,000 .{ }^{4}$ The inspiration for the AWVS was the organization of women in the United Kingdom who mobilized to help on the home front during WWII. Early in the conflict, British women recognized the importance of civilian aide during the crisis of war. The threat of an Axis attack on British soil, along with pressing social needs brought on by wartime society, led to the creation of the Women's Voluntary Service (WVS) in June of 1938. Among their many tasks, the women volunteers of the WVS set up and ran field kitchens, organized carpools, helped in search and rescue operations, salvaged materials, and aided in hospitals and clinics. At its peak, membership in the WVS during WWII reached about 1 million volunteers. ${ }^{5}$ Inspired by the WVS, Alice Throckmorton McLean, a social activist from a wealthy New York City family, founded the AWVS in January of 1940 with the broad mandate of wartime preparedness on the American home front. The passion with which McLean led the AWVS was evident from the first air-raid alarm sounded in her native New York City: "We shall remain on duty for 24 hours. Our Motor Corps and emergency kitchen will be drawn up outside the door ready to rush to any spot where there is a disaster. I have sent women downtown to hunt for tin helmets, and others are sewing armbands on their uniforms. I shall stay here all night." ${ }^{\prime \prime}$ The AWVS began as a small group but quickly expanded in both membership and mandate. Generally envisioned as a group

\footnotetext{
${ }^{4}$ Doris Weatherford, American Women and World War II (Edison, NJ: Castle Books, 1990), 233.

5 "Women at War," The National Archives, UK, accessed May 28, 2021, https://www.nationalarchives.gov.uk/education/homefront/women/wvs/default.htm. It's worth noting that the WVS continued as an organization after the war, changing its name to the Women's Royal Voluntary Service (WRVS) and more recently to the Royal Voluntary Service (RVS). Its current website and volunteer initiatives can be found here: https://www.royalvoluntaryservice.org.uk/.

6 “Civilian Defense: The Ladies!” Time, Monday, Jan. 26, 1942.
} 
to fill wartime needs, volunteers organized clothing drives, visited hospitalized soldiers, collected scraps, and sold war bonds. They were airplane spotters, truck drivers, firefighters, mechanics, photographers, and air-raid wardens. The women of the AWVS organized a vast network of educational campaigns in support of women who struggled to navigate this new wartime society. They held classes on repurposing old clothing, canning food, setting up Victory Gardens, rationing, and more.

Both on a national and local level, the AWVS proved instrumental to the success of home-front mobilization during WWII. With numerous community chapters, significant wartime initiatives, and proximity to the national AWVS in New York City, the New Jersey groups serve as a starting point for a more nuanced reflection on the AWVS during WWII. Along with considerations of gendered citizenship and volunteerism, the narrative of the AWVS presents women who both adhered to accepted forms of volunteerism and pushed social boundaries. ${ }^{7}$ The activities of the AWVS occupied a space somewhere in between nurturing and militaristic, blurring gendered lines of acceptable wartime participation and occupying a unique role not easily categorized. These women reimagined local activism and cooperation as encompassing more than their socially accepted supporting roles and expanded into areas of civilian defense, disaster response, emergency preparedness, and more. Furthermore, these volunteers operated on the ideology that community engagement was an essential part of the war effort, and pushed to unify volunteers into an effective and efficient force.

The advent of American participation in WWII initiated changes on the home front that were not easily remedied by federal intervention. Factories converted to wartime production, rationing presented new difficulties, and shortages of common items created the need to "make

\footnotetext{
${ }^{7}$ According to Meghan K. Winchell, gendered citizenship was work performed by women that "reinforced their primary peacetime roles as mothers and caregivers" (“To Make the Boys Feel at Home': USO Senior Hostesses and Gendered Citizenship," Frontiers: A Journal of Women's Studies, Vol. 25, No. 1 (2004): 191).
} 
do and mend." The large-scale absence of men as they left for military training and eventual deployment created disruptions on the home front not easily resolved. According to Susan M. Hartmann, "the Second World War transformed the economy, made unprecedented claims on women and men, and disrupted social arrangements on a broad scale." 8 The magnitude of challenges war brought to the home front created the need for civilian volunteers to take charge of their communities. In May of 1940, President Franklin D. Roosevelt signed Executive Order 8757, establishing the Office of Civilian Defense (OCD), with the aim of ensuring "effective coordination of Federal relations with state and local governments engaged in defense activities." ${ }^{\prime 9}$ However, the OCD suffered organizational problems from the beginning, and the AWVS jumped in to fill administrative and recruitment needs for the state and local groups. According to the National AWVS Bulletin, "One of the underlying purposes of the AWVS is to achieve a unity of women's efforts." 10 This mandate extended into other volunteer groups and influenced the wartime efforts of men, women, and children alike.

An emphasis on community involvement permeated the activities of the AWVS on both a national and local scale. As Betty Smith, author of the novel A Tree Grows in Brooklyn, wrote in a piece for the National AWVS Bulletin, "It is not a woman's privilege to help; it is her solemn duty and sacred obligation. The war will not be won by fighting alone. It will be won, too, by the women on the home front and in the armed services." 11 Virtually the only requirement for participation as an AWVS volunteer was the completion of 100 hours of training, making this organization a possible avenue of activism for many women during this time. Although the

\footnotetext{
${ }^{8}$ Susan M. Hartmann, The Homefront and Beyond: American Women in the 1940s (Boston: Twayne Publishers, 1982), ix.

${ }^{9}$ Franklin D. Roosevelt, Executive Order 8757 Establishing the Office of Civilian Defense. Online by Gerhard Peters and John T. Woolley, The American Presidency Project, https://www.presidency.ucsb.edu/node/209591. 10 "Personalities," The National Bulletin of the American Women's Voluntary Services, AWVS National Headquarters, New York City, Vol. 1, No. 5, November 1942.

${ }^{11}$ Betty Smith, "There are a Thousand ways you can Help," National AWVS Bulletin, June-July 1944.
} 
founders were upper-class socialites, the background of the general volunteer force varied. The AWVS eventually divided their efforts into different committees, each with volunteers specifically trained in relevant areas. One of the most visible initiatives of the AWVS was the Motor Corps, or the Motor Transport Division. The War Department supported the inclusion of the AWVS in transport services, stating "Authority is granted to commanding officers of posts, camps, and stations within the continental United States to make local arrangements for motor transport services rendered by the American Women's Voluntary Services, Inc." 12 Many of these women served on local military bases, shuttling troops and officers from one point to another. Mrs. Carl Surran, head of the Atlantic County New Jersey unit, recognized the importance of the Motor Transport, as well: "They will serve as guides at the base, also in the transportation service, using their own cars with gas okayed by the State Ration Board, through sanction of the Navy but paid for by themselves."13 This service released navy men who were previously assigned that duty. The women of the Motor Transport also drove civilians and other volunteers as needed. In New Jersey, AWVS drivers served at the Naval Air Station in Pomona, the Newark Army Air Base, Fort Monmouth, Fort Hancock, and many others.

An article in the Newark News exemplified the struggles of breaking preconceived gender roles, particularly for members of the Motor Corps, asking, "Does it take brains or brawn to drive a 10-ton, 16-wheel truck?"14 According to William E. Humphreys, president of Jacobs Transportation: “We can’t turn our garages into powder rooms. It would raise hell with morale. The men are tough and rough, that's what makes them good drivers. They'd become self-

\footnotetext{
12 “Motor Transport-American Women's Voluntary Services, Inc.” War Department of the United States, July 13, 1944.

13 “Mrs. Carl Surran to Head Unit of Women's Voluntary Services," Atlantic City Press, July 4, 1943.

14 "Hands that Rock Cradle also Capable of Driving big Trucks in Spite of Masculine Skepticism," Newark News, December 10, 1942.
} 
conscious with women around and resent the ladies' good manners." ${ }^{15}$ Jean Bernstein, an AWVS truck driver, retorted, “Oh Lord, that's nonsense . . . As for driving, we can handle anything with wheels, right up to 16 wheels."16 During WWII, military women, particularly those in the Women's Army Auxiliary Corps (WAAC), also served as truck drivers. In fact, recruits who received driver training through an AWVS program were more prepared to take on these responsibilities, and the War Department "requested the National Transportation Dept. of AWVS to furnish applicants to be WAAC drivers, feeling our training would make them more proficient than the average applicant." ${ }^{17}$ By training volunteers to drive trucks and perform tasks that often overlapped with those of military recruits, the AWVS reshaped the notions of what women's activism looked like. While some AWVS activities certainly fell within the boundaries of nurturing, others pushed the limits of what was considered socially acceptable behavior for women at the time. During WWII, the AWVS continuously pushed the limits of socially acceptable participation in women's volunteerism.

Members balanced their wartime contributions between the masculine and feminine. Disaster preparedness served as one example. AWVS women trained to respond to an emergency, such as a bombing on the home front, by learning to fight fires, triage the injured, and perform search and rescue operations. The Canteen Corps was responsible for providing food and drinks to service members, workers, and other community members. Volunteers were responsible for securing the necessary supplies and running the canteens. When a specific event was scheduled, like a large scrap drive, AWVS members set up canteens to feed those

\footnotetext{
15 Ibid.

${ }^{16}$ Ibid.

17 "WAAC want AWVS Drivers," The National Bulletin of the American Women's Voluntary Services, AWVS National Headquarters, New York City, Vol. 1, No. 5, November 1942.
} 
involved. ${ }^{18}$ Mock disasters were organized to train volunteers throughout the state. In March of 1941, the New York Times reported, "Some day next week a 'catastrophe' will occur somewhere in New Jersey and minutes later a mobile kitchen trailer, manned by members of the Harding Township unit of the American Women's Voluntary Services, will be speeding on its way to feed the 'victims' and render first aid."19 In a real-life example, the Harding Township AWVS set up a mobile kitchen for military members responding to a plane crash in Morristown, New Jersey. ${ }^{20}$ This unique blend of disaster response, medical intervention, and food distribution epitomized the AWVS's unique take on activism as all-encompassing.

The AWVS continued to gain strength throughout the U.S. during WWII. With a national motto of "Unite and Serve," the group brought together women from all backgrounds and collaborated with different groups like the USO and the American Red Cross. Through pamphlets and speeches, AWVS leadership stressed the importance of cooperation and selflessness in the face of a greater social good: "It is only when an ideal seems important enough to sweep away the differences of opinion or of tastes that a coordinated body can emerge .. . Let us not lose this opportunity for knowing and working with and finding out the best about our neighbors." ${ }^{21}$ In a 1942 Fireside Chat, Franklin D. Roosevelt emphasized the value of home-front cooperation, as well, stating, "There is one front and one battle where everyone in the United States - every man, woman, and child - is in action, and will be privileged to remain in action throughout this war. That front is right here at home, in our daily lives, [and] in our daily

\footnotetext{
18 "Canteen Corps plays Big Role in N.Y. Scrap Metal Drive," The National Bulletin of the American Women's Voluntary Services, AWVS National Headquarters, New York City, Vol. 1, No. 5, November 1942.

19 “Set New Jersey Run of Air Raid Kitchen," New York Times, March 23, 1941.

20 "Units at Work-New Jersey," The National Bulletin of the American Women's Voluntary Services, AWVS National Headquarters, New York City, Vol. 1, No. 5, November 1942.

21 "Personalities," The National Bulletin of the American Women's Voluntary Services, AWVS National Headquarters, New York City, Vol. 1, No. 5, November 1942.
} 
tasks." 22 The significance placed on community cooperation was represented in AWVS campaigns designed to guide home-front activities and help women cope with rationing and other material shortages. These activities included a major push on conservation efforts, including salvage, recycling grease and nylon, repurposing clothes, and donating unused items. Fashion shows, clothing-conservation courses, and pamphlets showed women how to repurpose old clothes into different styles. Of the many different tasks of the AWVS, public information campaigns and courses became popular. Such courses included information on how to set up mobile kitchens, canteen coordination, the basics of meat rationing, maintaining Victory Gardens, and more. ${ }^{23}$ Other community initiatives included civic engagement courses "to prepare women to vote intelligently in the upcoming presidential election." 24 Some volunteers led programs offering free driving lessons to veterans and even provided a car the individual could use to take their driver's test. ${ }^{25}$

While much AWVS work was similar across the state, some initiatives varied by location, as each chapter found "work appropriate to its town's needs." 26 With state headquarters in Newark, New Jersey, the AWVS spread throughout the Garden State easily. Local volunteers were trained in areas such as childcare, canning, map reading, home repairs, photography, switchboard operations, truck driving, and emergency response. Much like the USO, the AWVS was also concerned with keeping up the morale of the military. In this spirit, the AWVS launched the Victory Pastime Division to donate gifts to help injured servicemen. To keep soldiers occupied during their recovery, members of this committee secured crossword puzzles,

\footnotetext{
${ }^{22}$ Franklin D. Roosevelt, "Fireside Chat 21, April 28, 1942," The Miller Center of the University of Virginia, accessed: May 28. 2021, https://millercenter.org/the-presidency/presidential-speeches/april-28-1942-fireside-chat21-sacrifice.

23 “Advice on Meat Rationing," New York Times, March 28, 1943.

24 “AWVS Course to Aid Women Voters Here," New York Times, July 24, 1944.

25 "Veterans Taught to Drive by AWVS," New York Times, November 24, 1945.

26 "Saying it with Flowers: Oranges Chapter of AWVS Sends out 50 to 60 Bouquets each Week," Newark News, May 26, 1943.
} 
board games, magazines, musical instruments, Ping-Pong tables, and more. Volunteers furnished dayrooms at local posts and hospitals and even went shopping for Christmas gifts for military families. Volunteers filled specific military requests for technical materials as well. This division also “assisted other organizations such as the Citizen's Committee for the Army \& Navy, Bundles for Britain, Bundles for America, and the Hospital Library Bureau."27 Echoing FDR's belief that recreation was essential to the emotional well-being of citizens, the AWVS dedicated resources to ensure convalescing soldiers were occupied. This focus left a lasting impression on those who observed the impact of such efforts. First Lieutenant John W. Bishop wrote, "It is not necessarily the articles that are donated, but the thought behind such donations that makes these patients realize that while they are convalescing from injuries inflicted by the enemy, they are not forgotten men, and that all those who have stayed at home will never forget the job they have done. $" 28$

The women of the AWVS went to great lengths to boost the morale of the military, both on the home front and abroad. Unique to Millburn, a suburb in Essex County, New Jersey, the Township Tattle, a comical publication run by the local AWVS, was sent to soldiers from the area. The newsletter was founded in May 1942 and "edited by Mrs. Walter M. Taylor, with the assistance of Mrs. Egner, four reporters, three 'scribes,' a circulation manager and a two-lady "printing staff." 29 According to the writers, "we are of the firm opinion that a sense of humor is an essential item in the realization of victory." 30 With hundreds of copies mailed during the war,

\footnotetext{
27 "Victory Pastime Committee fills Requests Speedily," The National Bulletin of the American Women's Voluntary Services, AWVS National Headquarters, New York City, Vol. 1, No. 5, November 1942.

${ }^{28}$ John W. Bishop, Letter to the AWVS of Atlantic City, January 11, 1944.

29 "Millburn Boys the World Over Hold Fire to Praise AWVS," Newark News, March 12, 1943.

${ }^{30}$ Milburn Township Tattle, September 1942.
} 
military members wrote back to the paper as well. One soldier stationed in North Africa penned, "Dear Ladies, War is hell all right, but you're making it easier." 31

The AWVS Oranges chapter started an initiative to send bouquets of flowers to men staying at Halloran Hospital in Staten Island. ${ }^{32}$ Atlantic City struggled to accommodate an influx of soldiers and volunteers. Nicknamed "Camp Boardwalk," the bustling shore community became central to helping the war effort on the home front. By 1942, the military occupied the city, which provided both training and rehabilitation areas. The Army Air Corps Technical Training Command Center set up operations in Convention Hall, and five major hotels combined to create the Thomas England General Hospital, the largest in the U.S. during WWII. A commemorative plaque located in Resorts Casino reads, "From June of 1942 through November of 1945 , more than 300,000 men and women worked, trained and recuperated in Atlantic City also known as 'Camp Boardwalk.' During that time, more than 4,500 war casualties were treated at England General." ${ }^{33}$ With such a large influx of people, the Atlantic County AWVS fostered a network of essential services and support for soldiers and their families, volunteers, and workers. Elaine L. Gustafson, an AWVS volunteer in Atlantic City, recalled the soldiers at the Thomas England General Hospital: "Some of them were homesick and they wanted to tell us all about their families and their wives or children or girlfriends." 34 She went on, "We had parades on the boardwalk. Anything to lift the morale of the men ... We wrote letters home for them."35 Volunteers who frequented the Thomas England General Hospital brought board games, magazines, and other items to occupy convalescing troops, and staffed the library at the Atlantic

\footnotetext{
31 "Millburn Boys the World Over Hold Fire to Praise AWVS," Newark News, March 12, 1943.

32 "Saying it with Flowers: Oranges Chapter of AWVS Sends out 50 to 60 Bouquets each Week," Newark News, May 26, 1943.

33 “Camp Boardwalk,” Atlantic City Free Public Library, accessed May 11, 2021, http://www.acfpl.org/component/content/article?id=226:camp-boardwalk.

${ }^{34}$ Elaine L. Gustafson Collection

(AFC/2001/001/54674), Veterans History Project, American Folklife Center, Library of Congress.

35 Ibid.
} 
City Naval Air Station in Pomona, New Jersey, as well. ${ }^{36}$ Unique to Atlantic City, the local unit was responsible for running "the largest officers' club in the state in the Ritz Carlton Hotel for Army Air Forces personnel." 37

Guide services formed another significant service provided by the AWVS. For instance, members of the Oranges chapter served as guides at the Newark Airport and staffed its Officers Club. ${ }^{38}$ In Kearny, New Jersey, approximately half of all air-raid wardens were trained by local AWVS volunteers. ${ }^{39}$ With an eye toward the future, the AWVS trained a Junior Auxiliary of teenagers who wished to help the war effort. ${ }^{40}$ Local chapters found distinctive ways to raise money for wartime initiatives as well. The AWVS of the Oranges opened a shop to sell items and raise money for their community programs. Staffed by AWVS volunteers, the storefront sold household items and homemade baked goods. ${ }^{41}$

Throughout the war, a spirit of cooperation was pushed, particularly by FDR. In a State of the Union Address given in January of 1943, he insisted, "In our common labors we must build and fortify the very foundation of national unity-confidence in one another."42 Conservation took on a particular significance on the home front. A public information campaign including posters, articles, and pamphlets was launched to educate civilians on the importance of “(1) conserving, (2) recycling, (3) preparing food at home, (4) rationing, and (5) saving through

\footnotetext{
36 Ibid.

37 “AWVS holds Round Table Talks,” Newark News, March 4, 1944.

38 "Saying it with Flowers: Oranges Chapter of AWVS Sends out 50 to 60 Bouquets each Week," Newark News, May 26, 1943.

39 Ibid.

${ }^{40}$ Ibid.

41 “AWVS to Offer Wide Sales Variety," Newark News, October 21, 1943.

${ }^{42}$ Franklin Delano Roosevelt, "State of the Union Address, January 7, 1943," The Miller Center of the University of Virginia, accessed May 28, 2021, https://millercenter.org/the-presidency/presidential-speeches/january-7-1943-stateunion-address.
} 
war bonds." ${ }^{43}$ AWVS volunteers also formed a significant, and understated, part of this conservation push. Locally, these efforts were initiated by the AWVS, as members launched campaigns aimed at preserving materials and reusing old items. Fashion shows highlighted the unique ways clothing could be repurposed at home. AWVS women collected scrap metal, paper, nylons, leather bags, costume jewelry, fur coats, and more. A sewing unit knitted socks and sweaters for the military.

AWVS volunteers had a broad range of activities that touched virtually every area of home-front activity. They initiated educational programs to offer advice on how to navigate wartime society. With common slogans circulating like "Waste Helps the Enemy" and "When you Ride Alone, you Ride with Hitler," the conservation of materials was directly tied to ideas of patriotic duty and civic obligation. ${ }^{44}$ The pressure to know exactly what and how to conserve materials for the war effort fell on individuals with volunteer groups like the AWVS, who were doing their best to help. On a national level, the Salvage Program was endorsed by the Conservation Division of the War Department. ${ }^{45}$ The National AWVS stressed the importance of community cooperation and "the necessity for an ever-increasing salvage drive that should be the responsibility not only of the salvage committees but of every individual citizen in our nation."46 Salvage efforts in New Jersey included collecting cardboard, newspapers, magazines, metals, cooking fats, fabric, furs, nylons, and other scraps. ${ }^{47}$ At times, volunteers held large events in cooperation with local defense councils and often went door-to-door collecting items from

\footnotetext{
${ }^{43}$ Lauren Dalton, Pauline Sullivan, Jeanne Heitmeyer, and Ann DuPont, "Robertson's Model: A Framework for Exploration of World War II Conservation Consumption Policy Influence on Fashion in the US," International Journal of Consumer Studies, 36 (2012): 612.

44 "Powers of Persuasion," National Archives, accessed May 25, 2021, https://www.archives.gov/exhibits/powersof-persuasion\#use-up-wear-out.

45 "Salvage Endorsed," The National Bulletin of the American Women's Voluntary Services, AWVS National Headquarters, New York City, Vol. 1, No. 5, November 1942.

${ }^{46}$ Ibid.

47 “AWVS Salvage Committee Busy,” AWVS: Atlantic County Unit letter, February 15, 1945.
} 
individual households. The AWVS in Kearny, New Jersey, initiated "a house-to-house campaign to educate housewives in properly preparing fats for salvage, telling them what metals to save and how to process tin cans." ${ }^{48}$ The AWVS of Ridgewood, New Jersey, took charge of the salvage and fats collection programs for the entire county. ${ }^{49}$ Among the many campaigns in Atlantic City, New Jersey, a drive to collect warm clothes to send overseas to people in formerly Nazi-occupied territories was underway during most of the war. They also collected old fur coats to be repurposed into vests for the Merchant Marine (the Fur Vest Project). With an eye toward local issues, a sewing committee formed to make clothes for needy residents of the city. ${ }^{50}$

Another national wartime initiative that attempted to offset rationing shortages was the Victory Garden Program. Cecilia Gowdy-Wygant analyzed the vital nature of this program in her book Cultivating Victory: The Women's Land Army and the Victory Garden Movement. She wrote that "the seeds of victory were planted on farms, vacant lots, in backyards, rooftops, and window boxes." ${ }^{51}$ According to Gowdy-Wygant, conservation obligations on the home front fell mostly to women, and "With women's responsibility to recycle, ration, and plan came the added responsibility of growing vegetables to protect their children and their nations from hunger." 52 These programs were instigated in communities by local defense councils. In neighborhoods throughout the U.S., AWVS volunteers helped to organize programs and inform citizens of the best practices, pushing for "bigger and better gardens, productive from early spring to the hard

\footnotetext{
48 "Salvage Endorsed," The National Bulletin of the American Women's Voluntary Services, AWVS National Headquarters, New York City, Vol. 1, No. 5, November 1942.

${ }^{49}$ Ibid.

50 "AWVS Unit Reports on Activities," Atlantic City Press, December 8, 1943.

${ }^{51}$ Cecilia Gowdy-Wygant, Cultivating Victory: The Women's Land Army and the Victory Garden Movement (Pittsburgh, PA: The University of Pittsburgh Press, 2013), 1.

${ }^{52}$ Ibid., 184.
} 
freezes of winter." ${ }^{53}$ AWVS volunteers also educated citizens on canning practices and encouraged the donation of any extra food to local schools.

AWVS educational initiatives focused on giving citizens the tools to make informed and independent decisions during this time. Besides classes on rationing, canning, gardening, salvage, and more, the AWVS also offered insights into consumer issues. Volunteers with the consumer information program organized and delivered material on "anti-inflation measures, price control, and rationing," while other noted responsibilities included acting as mediators in disputes between customers and companies and giving advice on the proper agencies to consult for any issues. ${ }^{54}$

With committees being added to meet new wartime needs, the AWVS quickly situated itself as an administrative leader. Impressively, their proven track record and notable structural aptitude allowed the AWVS to work with other organizations such as the American Red Cross. One of the most effective collaborations between these groups during WWII was the Blood Donor Campaign, which canvassed areas for donations and secured lifesaving blood for the Allied war effort. The AWVS helped organize volunteers, distributed publicity, and went doorto-door to solicit donations. ${ }^{55}$ Both nationally and locally, the collaborative record of the AWVS included work with different volunteer associations, government organizations, and religious and civic groups. For the AWVS, the mandate to "Unite and Serve" was much more than a guiding principle for its members but an all-encompassing ideology to be applied to every individual and organization working toward the war effort in some way.

53 "Victory Gardens, 1943," The National Bulletin of the American Women's Voluntary Services, AWVS National Headquarters, New York City, Vol. 1, No. 5, November 1942.

54 "Consumers to be Aided by AWVS Unit," The National Bulletin of the American Women's Voluntary Services, AWVS National Headquarters, New York City, Vol. 1, No. 5, November 1942.

55 American Women's Voluntary Services, Public Relations Department, AWVS Publications Department Monthly Report, December 1943, https://texashistory.unt.edu/ark:/67531/metapth978191/: accessed October 15, 2021), University of North Texas Libraries, The Portal to Texas History, https://texashistory.unt.edu; crediting Rosenberg Library. 
This attempted inclusivity of the AWVS marked a significant and unique characteristic during this time. However, segregation policies and discrimination still permeated the organization. The AWVS came under national scrutiny for the treatment of African American members during WWII. In Double Victory: How African American Women Broke Race and Gender Barriers to Help Win World War II, Cheryl Mullenbach details the struggle of Black women as volunteers within the AWVS, describing their status as occupying a role that fell somewhere short of full membership. She writes, "While the group members were united in their goals, they did not serve equally. White women held the top leadership roles, while black women were welcome only as workers who had to operate in groups separate from white groups." ${ }^{56}$ In one well-known instance, Lugenia Burns Hope, Grace Nail Johnson, and Osceola Macarthy Adams, all recognized community activists, quit the Harlem AWVS when segregated chapters were established. Johnson maintained that the AWVS treated Black women as "a fragmentary part of its organization" and refused to allow them to serve on committees or in leadership roles. ${ }^{57}$ Despite claims of equality, training classes offered by the AWVS remained segregated. ${ }^{58}$

While volunteer associations such as the USO and the American Red Cross have garnered more academic consideration recently, the AWVS has either been ignored altogether or glossed over briefly. Given the organization's wide range of wartime activities, famous members like Hattie McDaniel, Betty White, and Joan Crawford, and the impressive number of clubs and volunteers operating during WWII, the lack of scholarly attention afforded to this group is puzzling. Perhaps the overlap of similar activities the AWVS shared with other organizations such as the American Red Cross, USO, and the Office of Civilian Defense provides a partial

\footnotetext{
${ }^{56}$ Cheryl Mullenbach, Double Victory: How African American Women Broke Race and Gender Barriers to Help Win World War II (Chicago: Chicago Review Press, 2017), 156.

57 "Anti-Negro Bias Denied by AWVS; Example of Equality Cited as Three Leaders Quit Harlem Unit in Protest," New York Times, February 26, 1942.

${ }^{58}$ Mullenbach, 156.
} 
explanation. Another possibility is that the original reason for the group's existence, preparation for an Axis attack on the American home front, never materialized. However, the group did not limit itself to preparedness and quickly branched off into virtually every area of home-front mobilization. Maybe the longevity (or lack thereof) of the group provides some explanation. While the AWVS was officially disbanded after WWII, groups like the USO and Red Cross continued and proved instrumental in subsequent conflicts. Whatever the reason for its relative absence from the historiography, the AWVS was undeniably an essential part of the war effort. A comprehensive analysis of its impact, both nationally and locally, is necessary in gaining a more complete picture of women's volunteer efforts on the home front. Existing scholarship has detailed the necessity of home-front mobilization, particularly the vast networks of volunteers who rationed, raised Victory Gardens, repurposed old clothes, rolled bandages, set up USO centers, transported troops, and much more. With hundreds of thousands of volunteers, chapters all over the country, and a vast array of wartime campaigns, the women of the AWVS played an influential part in successfully mobilizing the American home front. A more nuanced examination of these volunteers and the AWVS is a necessary contribution to the continually growing scholarship on women in WWII. 


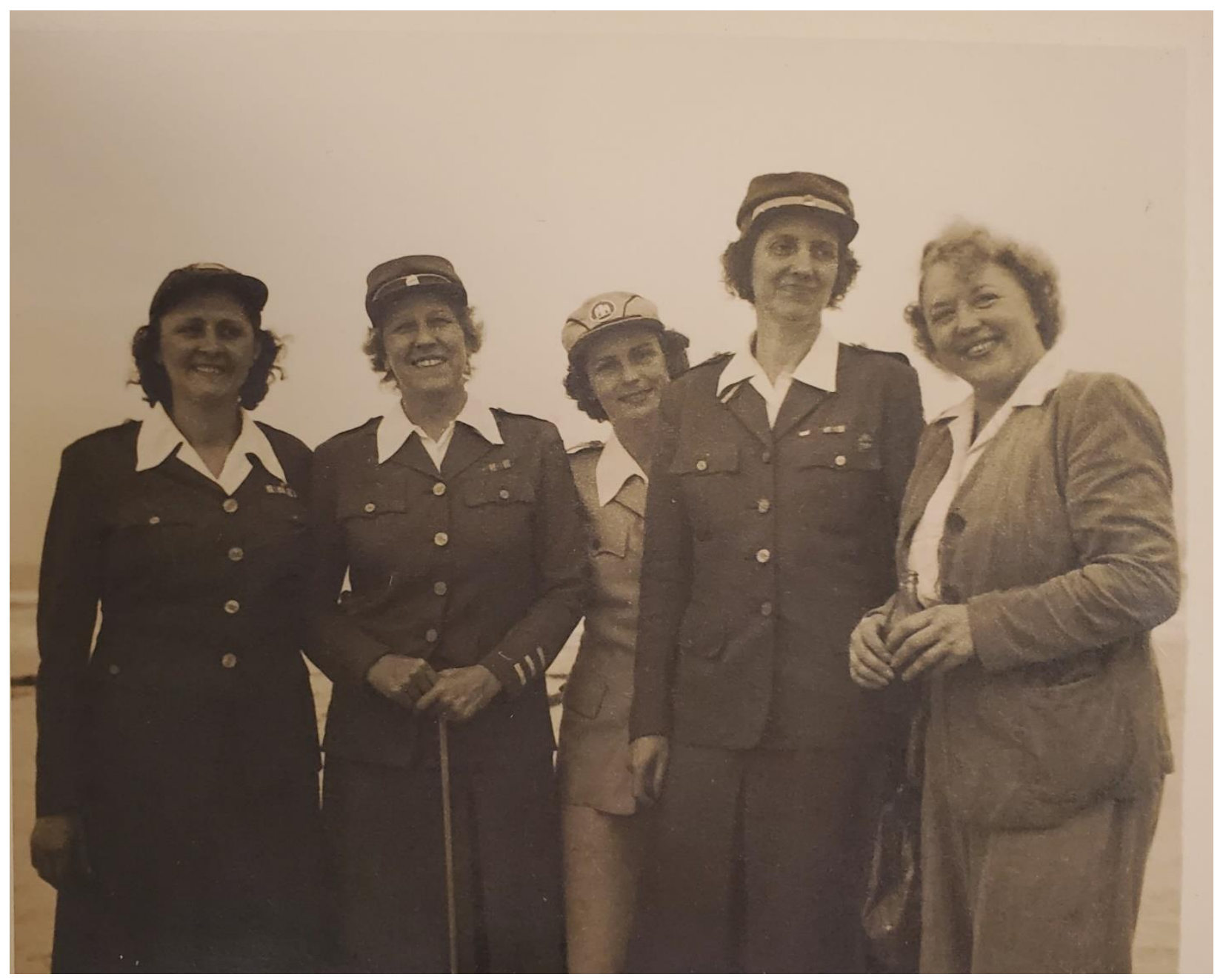

Atlantic County AWVS Unit. Courtesy of the Atlantic County Historical Society. 


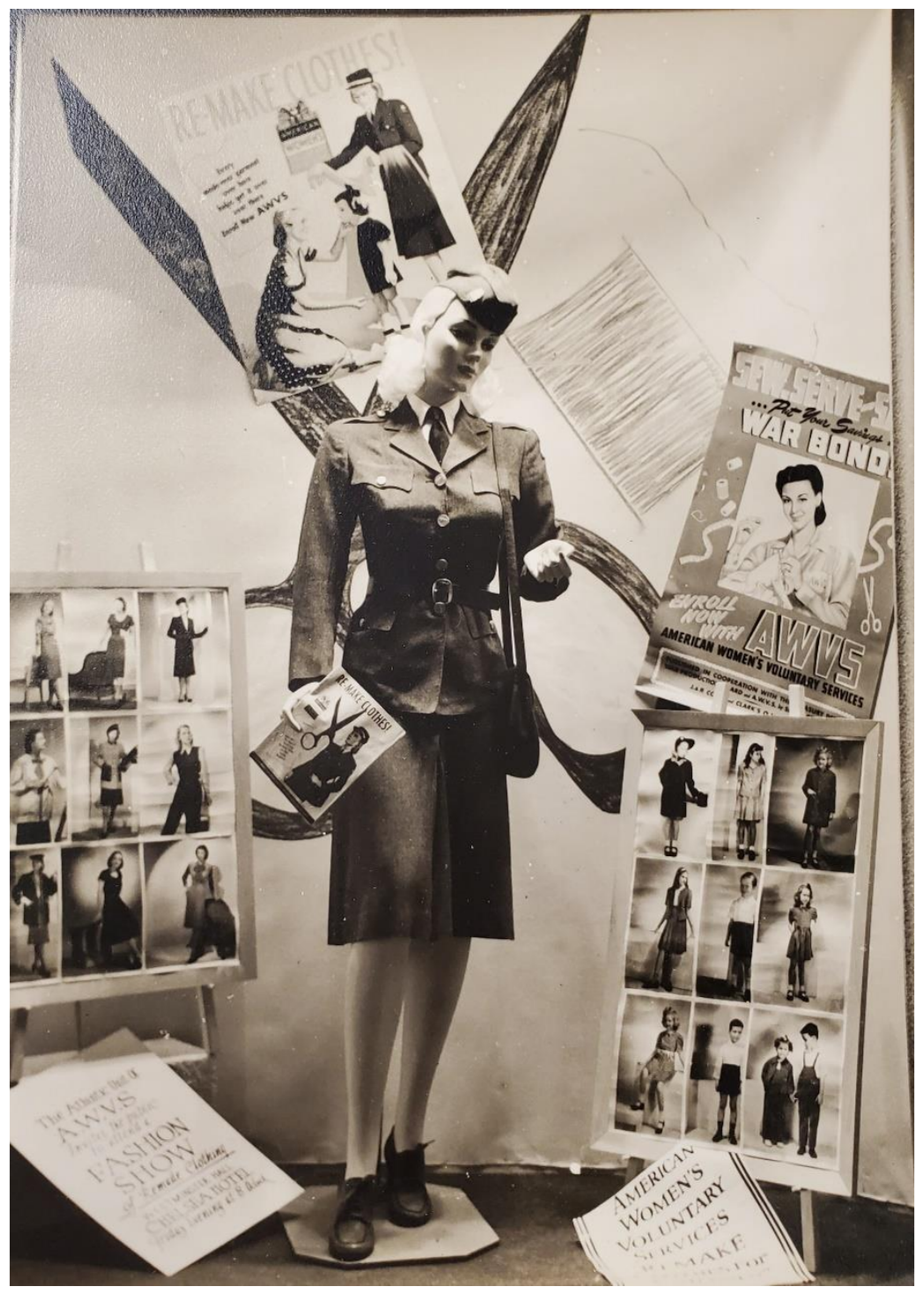

AWVS Fashion Show Display. Courtesy of the Atlantic County Historical Society.

Patty Chappine is an adjunct professor at Stockton University, where she teaches courses in the Holocaust and Genocide Studies and Historical Studies programs. She is also an adjunct in the Holocaust and Genocide Studies graduate program at Gratz College. She earned a BA in sociology and an MA in Holocaust and Genocide Studies from Stockton University. She also earned an MA and a PhD in History and Culture from Drew University in Madison, New Jersey. 
Her research interests include Holocaust and genocide studies, women's history, New Jersey history, digital humanities, and civic activism. 